\title{
Implementasi Composite Performance Index pada Multi Criteria Decision Making (MCDM) untuk Memilih Lokasi Usaha UMKM
}

\author{
Diana \\ Dosen Universitas Bina Darma \\ Jalan Jenderal Ahmad Yani No.3 Palembang \\ Sur-el : diana@binadarma.ac.id.
}

\begin{abstract}
The selection of the right location for Micro, Small and Medium Enterprises (MSMEs) will have a positive influence on the development of MSMEs and is expected to provide optimal income. The criteria used to select MSME businesses are place rental costs, availability of electricity, availability of clean water, road access, parking area, level of security, proximity to suppliers, similar business and population density of implementation. The Composite Performace Index (CPI) for choosing a location produces location 4 as the best location. In this paper, a single dimension weight sensitivity test is carried out to see the stability of the CPI by conducting trials on 6 variations in the criteria weight. The sensitivity test results that the CPI local weight stability interval is $0.01 \leq C P I \leq 0.41$, where Location 4 is in the first rank position. The results of the global weight stability interval are at intervals of $0.01 \leq C P I \leq 0.21$, where the results of the ranking position of all alternative business locations do not change.
\end{abstract}

Keywords : Business Location, Keputusan Multi Kriteria, MCDM, Indeks Kinerja Gabungan, $C P I$

\begin{abstract}
Abstrak. Pemilihan lokasi Usaha Mikro Kecil Menengah (UMKM) yang tepat akan memberi pengaruh positif terhadap perkembangan UMKM dan diharapkan dapat memberikan hasil pendapatan yang optimal. Kriteria yang digunakan untuk memilih usaha UMKM adalah biaya sewa tempat, ketersediaan listrik, ketersediaan air bersih, akses jalan, luas lahan parkir, tingkat keamanan, kedekatan dengan suplier, usaha serupa dan kepadatan penduduk implementasi. Composite Performace Index (CPI) untuk memilih lokasi menghasilkan lokasi 4 sebagai lokasi terbaik. Pada tulisan ini, dilakukan uji sensitivitas bobot dimensi tunggal untuk melihat kestabilan CPI dengan melakukan ujicoba pada 6 variasi bobot kriteria. Hasil uji sensitivitas bahwa interval stabilitas bobot lokal CPI adalah 0,01 $\leq C P I \leq 0,41$, dimana diperoleh Lokasi 4 berada pada posisi peringkat pertama. Hasil interval stabilitas bobot global berada pada interval 0,01 $\leq C P I \leq 0,21$, dimana hasil posisi pemringkatan semua alternatif lokasi usaha tidak berubah.
\end{abstract}

Kata Kunci : Lokasi Usaha, Multi Criteria Decision Making, MCDM, Composite Performance Index, $C P I$

\section{PENDAHULUAN}

Cara memilih lokasi Usaha Mikro Kecil Menengah (UMKM) akan mempengaruhi kesuksesan usaha yang dilakukan. Pemilihan lokasi usaha yang tepat akan memberi pengaruh positif terhadap perkembangan bisnis dimasa yang akan datang dan sebaliknya pemilihan lokasi UMKM yang tidak tepat dapat mengakibatkan usaha tidak berjalan sesuai yang diharapkan. Pemilihan lokasi UMKM yang tepat merupakan hal yang sangat penting untuk mendapatkan keuntungan pendapatan yang optimal dan mempengaruhi tingkat kesuksesan UMKM. (Hanggita, 2018), Pemilihan lokasi usaha dipengaruhi beberapa faktor berbeda penerapannya bagi satu usaha dengan usaha lain sesuai produk dan jasa yang dihasilkan. 
Ketepatan dalam pemilihan lokasi merupakan salah satu faktor yang dipertimbangkan oleh pelaku usaha sebelum membuka usahanya. Pemilihan lokasi yang strategis dan dekat dengan konsumen ataupun pasar akan mempengaruhi sukses atau tidaknya suatu usaha. Kesalahan dalam menentukan lokasi usaha harus diminimumkan sehingga usaha yang dioperasikan dapat beroperasi secara efektif dan efisien. Namun, kenyataan yang sering terjadi adalah bahwa setiap usaha akan memiliki kebutuhan karakteristik lokasi usaha yang berbeda dan bukan perkara mudah untuk mendapatkan lokasi usaha yang strategis dengan keterbatasan modal yang ada. Ada berbagai kriteria yang dapat digunakan untuk memilih lokasi usaha yang tepat, efektif dan efisien.

Memilih lokasi usaha sangat ditentukan oleh aspek lingkungan sekitar lokasi. Menurut (Fu'ad, 2015) kedekatan dengan infrastruktur, kondisi lingkungan bisnis dan biaya lokasi memiliki korelasi positif terhadap kesuksesan usaha berskala mikro/kecil Shopping Center Jepara. Variabel biaya lokasi memiliki pengaruh besar terhadap kesuksesan usaha, artinya semakin besar biaya yang harus pemilik usaha untuk memperoleh lokasi maka semakin tinggi kemungkinan memperoleh kesuksesan. Variabel biaya lokasi terdiri dari biaya sewa tempat, kebutuhan renovasi / penataan tempat usaha, tarif pajak yang harus dibayar, tingkat suku bunga. Variabel kedekatan dengan infrastruktur terdiri dari ketersediaan air bersih, pasokan listrik, keberadaan jalan beraspal, ketersediaan lahan parkir di lokasi usaha. Variabel kondisi lingkungan bisnis terdiri dari kedekatan usaha dengan konsumen, pesaing, jenis usaha lain, pemasok. Sedangkan (Hanggita, 2018) menyatakan bahwa faktor yang menjadi pertimbangan dalam pemilihan lokasi usaha jasa pada UMKM adalah tenaga kerja, akses, fasilitas, pasar, energi, persaingan dan peraturan pemerintah. Faktor akses, fasilitas, pasar dan energi termasuk kategori faktor yang sangat penting. Sedangkan faktor tenaga kerja, persaingan dan peraturan pemerintah termasuk kategori faktor yang penting. (Fathoni, 2016) juga menuliskan bahwa biaya lokasi dan lingkungan bisnis berpengaruh signifikan terhadap tingkat penjualan pada usaha jasa mikro, sedangkan infrastuktur tidak berpengaruh signifikan. Dari ketiga variabel ini, variabel lingkungan bisnis merupakan variabel yang paling berpengaruh dominan. Kedekatan dengan infrastruktur terdiri dari ketersediaan listrik, ketersediaan air bersih, adanya akses jalan beraspal. Ketersediaan lahan parkir dan tingkat tempat usaha, adanya tindakan biaya renovasi, ada/tidaknya insentif bangunan, besarnya pajak dan tingkat suku bunga. Lingkungan bisnis terdiri dari kedekatan dengan bisnis jasa lain, kedekatan dengan konsumen, kedekatan dengan pesaing, kelengkapan peralatan.

Memilih lokasi usaha terbaik dari beberapa lokasi usaha yang ada sehingga diperoleh sebuah keputusan yang terbaik, dimana keputusan ini sendiri adalah hasil proses memilih pilihan terbaik diantara beberapa alternatif yang telah tersedia. Pada proses pengambilan keputusan, kita akan berusaha mencurahkan segala pemikiran untuk mendapatkan pilihan yang terbaik (Diana, 2018). Masalah yang sedang dibahas ini termasuk keamanan. Biaya lokasi terdiri dari harga sewa 
dalam bidang ilmu Multi Criteria Decision Making (MCDM). Menurut (Rekik et al., 2016) perkembangan publikasi tentang MCDM sampai tahun 2015 mencapai 500 buah publikasi. Penggunaan MCDM menyebar pada berbagai bidang keilmuan. Bidang-bidang ini meliputi : bidang ekonomi, ekonometrik dan keuangan (4\%), bidang ilmu lingkungan (10\%), bidang ilmu kemasyarakatan $(11,4 \%)$, bidang obatobatan $(12,3 \%)$, bidang bisnis, manajemen dan akuntansi (13,4\%), Engineering (34,3\%), computer science (33\%), matematika (18,9\%), ilmu keputusan $(17,8 \%)$ dan bidang lainnya (26,3\%). (Rostamzadeh, Ismail and Bodaghi Khajeh Noubar, 2014) menuliskan bahwa MCDM dapat membantu pembuat keputusan untuk menentukan alternatif terbaik sesuai dengan karakteristik setiap kasus. Teknik MCDM ini merupakan alat yang ampuh dan banyak digunakan untuk mengevaluasi dan melakukan pemeringkatan alternatif dengan kriteria yang saling bertentangan.

Terdapat banyak metode yang dapat digunakan dalam MCDM. (Diana, 2017) metode Bayes dapat digunakan dalam proses pengambilan keputusan multikriteria. Dan (Rostamzadeh, Ismail and Bodaghi Khajeh Noubar, 2014) mengevaluasi dan menentukan prioritas intensitas pada SMEs menggunakan MCDM, untuk menentukan bobot kriteria dan subkriteria digunakan F-AHP dan untuk pemringkatan akhir perusahaan digunakan metode VIKOR. (Diana, 2016) membangun sistem pendukung keputusan dengan mengimplementasi metode SMART untuk menentukan kelayakan bisnis. (Arlida, C.P.,
Suryatiningsih, Adi, 2012) membangun sistem pendukung keputusan dengan mengimplementasi CPI untuk menentukan jenis bibit tanaman pada penjualan online. Sistem yang dihasikan dapat membantu pelanggan untuk memilih jenis bibit tanama sesuai dengan kondisi tempat tinggal pelanggan. (Karismariyanti, 2011) membangun sistem pendukung keputusan dengan mengimplementasikan CPI untuk menentukan penerima beasiswa. CPI mampu mentrasformasikan skala yang berbeda menjadi nilai yang seragam sehingga diperoleh nilai alternatif, alternatif-alternatif yang sudah terurut berdasarkan nilai tersebut akan membantu pengambil keputusan sehingga memiliki penilai yang sama terhadap satu alternatif.

\section{METODOLOGI PENELITIAN}

\subsection{Langkah Penelitian}

Langkah penelitian yang dilakukan adalah :

1) Mengumpulkan data;

2) Implementasi CPI untuk memilih lokasi usaha UMKM;

3) Melakukan uji sensitivitas bobot dimensi tunggal;

\subsection{Composite Performance Index (CPI)}

(Rahim et al., 2017), CPI dapat digunakan sebagai bantuan proses untuk pengambilan untuk meminimalkan kesalahan dan penerimaan subjektif keputusan, metode penghitungan CPI dapat juga dihitung secara manual dan mudah 
terutama jika diterapkan dalam bentuk aplikasi yang akan memungkinkan semua pihak untuk mendapatkan hasil yang akurat. Menurut (Pandian, Jawahar and Nachiappan, 2013), CPI dikembangkan untuk keberlanjutan yang dapat berguna untuk menilai kinerja industri.

Pada CPI terdapat 2 tren kriteria yaitu trend positif dan trend negatif.

1) Kriteria trend positif adalah kriteria yang semakin tinggi nilainya maka semakin baik. Pada kriteria ini, nilai minimum pada setiap kriteria ditransformasikan ke nilai 100 dan nilai lainnya ditransformasikan secara proposional ke nilai yang lebih tinggi.

2) Kriteria trend negatif adalah kriteria yang semakin rendah nilainya maka semakin baik. Pada kriteria ini, nilai minimum pada setiap kriteria ditransformasikan ke nilai 100 dan nilai lainnya ditransformasikan secara proporsional ke nilai yang lebih rendah.

3) Nilai alternatif diperoleh dengan cara menjumlahkan perkalian antara nilai kriteria dengan bobot kriteria.

Nilai CPI dapat dicari dengan menggunakan persamaan (Rahim et al., 2017),

$$
\begin{aligned}
& \operatorname{Trend}(-)=\frac{\text { Value Min }}{\text { Value } N} * 100 \\
& \operatorname{Trend}(+)=\frac{\text { Value } N}{\text { Value Min }} * 100
\end{aligned}
$$

Nilai CPI direpresentasikan dalam matrik, $\mathrm{V}_{\mathrm{ij}}$,

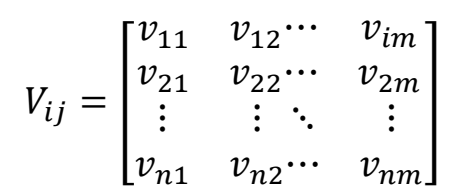

Menentukan peringkat setiap alternatif dapat dihitung dengan menggunakan persamaan,

$$
\sum_{j=1}^{m} W_{j}=1.0
$$

$$
N A_{i}=\sum_{i=1}^{n} \sum_{j=1}^{m} V_{i j} * W_{j}
$$

Keterangan :

$\mathrm{n}=$ Banyak alternatif; $\mathrm{i}=1,2, \ldots, \mathrm{n}$

$\mathrm{m}=$ Banyak Kriteria; $\mathrm{j}=1,2, \ldots, \mathrm{m}$

$\mathrm{NA}_{\mathrm{i}}=$ Total nilai akhir alternatif ke $\mathrm{i}$

$\mathrm{V}_{\mathrm{ij}}=$ Nilai CPI alternatif ke i untuk kriteria ke $\mathrm{j}$

$\mathrm{W}_{\mathrm{j}}=$ Tingkat kepentingan (bobot) kriteria ke $\mathrm{j}$

\subsection{Kriteria dan Alternatif}

Kriteria yang digunakan adalah :

Tabel 1. Kriteria yang Digunakan

\begin{tabular}{ccc}
\hline $\begin{array}{c}\text { Kode } \\
\text { Kriteria }\end{array}$ & Kriteria & Satuan Data \\
\hline $\mathrm{C}_{1}$ & $\begin{array}{c}\text { Biaya sewa } \\
\text { tempat } \\
\text { Ketersediaan } \\
\text { Listrik }\end{array}$ & Rupiah \\
$\mathrm{C}_{2}$ & Watt \\
$\mathrm{C}_{3}$ & $\begin{array}{c}\text { Ketersediaan Air } \\
\text { Bersih }\end{array}$ & Skala Linkert \\
$\mathrm{C}_{4}$ & Akses Jalan & $\begin{array}{c}\text { Lebar Jalan } \\
(\text { meter })\end{array}$ \\
$\mathrm{C}_{5}$ & $\begin{array}{c}\text { Luas Lahan } \\
\text { Parkir }\end{array}$ & $\mathrm{M}^{2}$ \\
$\mathrm{C}_{6}$ & Tingkat & Skala Linkert \\
$\mathrm{C}_{7}$ & $\begin{array}{c}\text { Keamanan } \\
\text { Kedekatan } \\
\text { dengan suplier }\end{array}$ & Jarak (Km) \\
$\mathrm{C}_{8}$ & Usaha Serupa & Unit \\
$\mathrm{C}_{9}$ & $\begin{array}{c}\text { Kepadatan } \\
\text { Penduduk }\end{array}$ & $\mathrm{Km}^{2} / \mathrm{Jiwa}$ \\
& &
\end{tabular}

Alternatif pada sistem ini adalah data masing-masing lokasi berdasarkan ke sembilan kriteria yang ada.

\subsection{Analisis Sensitivitas Bobot}

Uji stabilitas CPI menggunakan analisis sensitivitas bobot dimensi tunggal. Pada pendekatan ini, bobot kriteria yang paling penting menurun dan meningkat dalam kisaran yang ditentukan dan kriteria lainnya akan menurun dan meningkat secara proporsional. 
Kisaran bobot kriteria terpenting antara 0 sampai $\mathrm{W}_{\mathrm{j}}^{\prime}$, nilai $\mathrm{W}_{\mathrm{j}}^{\prime}$ ditentukan menggunakan persamaan (Karande, Zavadskas and Chakraborty, 2016):

$$
W^{\prime}{ }_{j}=\left[\left(W_{j \max }+(n-1) x W_{j \min }\right)\right]
$$

Keterangan :

$\mathrm{W}_{\mathrm{j}}^{\prime}=$ Nilai kisaran tertinggi bobot kriteria terpenting

$\mathrm{n}=$ Banyak kriteria

$\mathrm{W}_{\text {jmax }}=$ Bobot kriteria tertinggi

$\mathrm{W}_{\mathrm{jmin}}=$ Bobot kriteria terendah

Pada tulisan ini, akan dilakukan ujicoba dengan menggunakaan enam buah variasi bobot kriteria, lalu akan ditentukan interval stabilitas bobot lokal dan interval stabilitas bobot global. Interval stabilitas bobot lokal diindikasikan sebagai kisaran bobot dimana peringkat alternatif terbaik tidak berubah. Interval stabiltas bobot global diindikasikan sebagai kisaran bobot dimana peringkat semua alternatif tidak berubah.

\section{HASIL DAN PEMBAHASAN}

\subsection{Bobot dan Trend Kriteria}

Pada CPI ada 2 jenis trend kriteria yaitu trend kriteria positif dan trend kriteria negatif. Pengambil keputusan yang menentukan trend kriteria. Misalkan pada kriteria ketersediaan listrik, pengambil keputusan A bisa jadi menentukan kriteria ketersediaan listrik ini sebagai kriteria negatif, yang artinya semakin kecil harga sewa semakin diinginkan, namun bisa jadi juga pengambil keputusan B menentukan kriteria ketersediaan listrik ini sebagai kriteria positif, yang artinya semakin besar harga sewa semakin baik. Penentuan trend kriteria ini ditentukan oleh pengambil keputusan berdasarkan pada keadaan dan kebutuhan suatu usaha.

Tabel 2. Bobot dam Trend Kriteria

\begin{tabular}{ccc}
\hline Kode Kriteria & Bobot & Trend \\
\hline $\mathrm{C}_{1}$ & 0,09 & Negatif \\
$\mathrm{C}_{2}$ & 0,08 & Positif \\
$\mathrm{C}_{3}$ & 0,13 & Positif \\
$\mathrm{C}_{4}$ & 0,05 & Positif \\
$\mathrm{C}_{5}$ & 0,09 & Positif \\
$\mathrm{C}_{6}$ & 0,11 & Positif \\
$\mathrm{C}_{7}$ & 0,19 & Negatif \\
$\mathrm{C}_{8}$ & 0,14 & Negatif \\
$\mathrm{C}_{9}$ & 0,12 & Positif \\
\hline
\end{tabular}

\subsection{Konversi Nilai}

Kriteria Ketersediaan Air Bersih $\left(\mathrm{C}_{3}\right)$ memiliki nilai kualitatif sehingga harus diubah menjadi nilai kuantitatif untuk proses perhitungan CPI. Konversi nilai untuk kriteria dapat dilihat pada tabel 3.

Tabel 3. Konversi untuk Nilai Kriteria $C_{3}$

\begin{tabular}{cc}
\hline $\begin{array}{c}\text { Nilai Ketersediaan Air } \\
\text { Bersih }\end{array}$ & $\begin{array}{c}\text { Konversi } \\
\text { Nilai }\end{array}$ \\
\hline Sangat Baik Sekali & 5 \\
Baik & 4 \\
Cukup Baik & 3 \\
Tidak Baik & 2 \\
Sangat Tidak Baik & 1 \\
\hline
\end{tabular}

Demikian juga kriteria Tingkat Keamanan $\left(\mathrm{C}_{6}\right)$ juga memiliki nilai kualitatif sehingga harus diubah menjadi nilai kuantitatif untuk proses perhitungan CPI. Konversi nilai untuk kriteria ini dapat dilihat pada tabel 4. 
Tabel 4. Konversi untuk Nilai Kriteria $\mathrm{C}_{6}$

\begin{tabular}{cc}
\hline $\begin{array}{c}\text { Nilai Tingkat } \\
\text { Keamanan }\end{array}$ & $\begin{array}{c}\text { Konversi } \\
\text { Nilai }\end{array}$ \\
\hline Sangat Aman Sekali & 5 \\
Aman & 4 \\
Cukup Aman & 3 \\
Tidak Aman & 2 \\
Sangat Tidak Aman & 1 \\
\hline
\end{tabular}

\subsection{Simulasi Perhitungan CPI}

Ada 4 lokasi usaha yang akan digunakan dalam simulasi perhitungan sebagai contoh implementasi Composite Performance Index (CPI) dalam proses perhitungan menentukan lokasi usaha. Nilai data kriteria $\mathrm{C}_{3}$ dan $\mathrm{C}_{6}$ pada data testing diatas masih berupa data kualitatif. Kita melakukan konversi nilai berdasarkan pada tabel 3, sehingga dihasilkan tabel 5 dan tabel 6 .

Perhitungan CPI untuk masing-masing alternatif pada masing-masing kriteria dilakukan menggunakan persamaan 1 untuk kriteria trend negatif dan menggunakan persamaan 2 untuk kriteria trend positif.

Perhitungan CPI untuk kriteria biaya sewa tempat $\left(\mathrm{C}_{1}\right)$,

$\mathrm{L}_{1} \cdot \mathrm{C}_{1}(-)=\frac{2,1}{2,1} * 100=100$

$\mathrm{L}_{2} \cdot \mathrm{C}_{1}(-)=\frac{2,1}{3,2} * 100=66$

$\mathrm{L}_{3} \cdot \mathrm{C}_{1}(-)=\frac{2,1}{2,9} * 100=72$

$\mathrm{L}_{4} \cdot \mathrm{C}_{1}(-)=\frac{2,1}{2,5} * 100=84$

Perhitungan CPI untuk kriteria ketersediaan listrik $\left(\mathrm{C}_{2}\right)$,

$\mathrm{L}_{1} \cdot \mathrm{C}_{2}(+)=\frac{900}{900} * 100=100$

$\mathrm{L}_{2} \cdot \mathrm{C}_{2}(+)=\frac{1200}{900} * 100=133$

$\mathrm{L}_{3} \cdot \mathrm{C}_{2}(+)=\frac{900}{900} * 100=100$
$\mathrm{L}_{4} \cdot \mathrm{C}_{2}(+)=\frac{2200}{900} * 100=244$

Perhitungan CPI untuk kriteria ketersediaan air bersih $\left(\mathrm{C}_{3}\right)$,

$\mathrm{L}_{1} \cdot \mathrm{C}_{3}(+)=\frac{3}{3} * 100=100$

$\mathrm{L}_{2} \cdot \mathrm{C}_{3}(+)=\frac{4}{3} * 100=133$

$\mathrm{L}_{3} . \mathrm{C}_{3}(+)=\frac{5}{3} * 100=167$

$\mathrm{L}_{4} \cdot \mathrm{C}_{3}(+)=\frac{4}{3} * 100=133$

Perhitungan CPI untuk kriteria akses jalan $\left(\mathrm{C}_{4}\right)$,

$\mathrm{L}_{1} \cdot \mathrm{C}_{4}(+)=\frac{8}{5} * 100=160$

$\mathrm{L}_{2} \cdot \mathrm{C}_{4}(+)=\frac{7}{5} * 100=140$

$\mathrm{L}_{3} \cdot \mathrm{C}_{4}(+)=\frac{5}{5} * 100=100$

$\mathrm{L}_{4} \cdot \mathrm{C}_{4}(+)=\frac{6}{5} * 100=120$

Perhitungan CPI untuk kriteria luas lahan parkir $\left(\mathrm{C}_{5}\right)$,

$\mathrm{L}_{1} \cdot \mathrm{C}_{5}(+)=\frac{50}{50} * 100=100$

$\mathrm{L}_{2} \cdot \mathrm{C}_{5}(+)=\frac{100}{50} * 100=200$

$\mathrm{L}_{3} \cdot \mathrm{C}_{5}(+)=\frac{70}{50} * 100=140$

$\mathrm{L}_{4} \cdot \mathrm{C}_{5}(+)=\frac{80}{50} * 100=160$

Perhitungan CPI untuk kriteria tingkat keamanan $\left(\mathrm{C}_{6}\right)$,

$$
\begin{aligned}
& \mathrm{L}_{1} \cdot \mathrm{C}_{6}(+)=\frac{5}{3} * 100=167 \\
& \mathrm{~L}_{2} \cdot \mathrm{C}_{6}(+)=\frac{4}{3} * 100=133 \\
& \mathrm{~L}_{3} \cdot \mathrm{C}_{6}(+)=\frac{3}{3} * 100=100 \\
& \mathrm{~L}_{4} \cdot \mathrm{C}_{6}(+)=\frac{4}{3} * 100=133
\end{aligned}
$$


Tabel 5. Data Testing

\begin{tabular}{lcccccccccc}
\hline $\begin{array}{l}\text { Kode } \\
\text { Lokasi }\end{array}$ & Lokasi & $\begin{array}{c}\mathbf{C}_{\mathbf{1}} \\
(-)\end{array}$ & $\begin{array}{c}\mathbf{C}_{\mathbf{2}} \\
(+)\end{array}$ & $\begin{array}{c}\mathbf{C}_{\mathbf{3}} \\
(+)\end{array}$ & $\begin{array}{c}\mathbf{C}_{\mathbf{4}} \\
(+)\end{array}$ & $\begin{array}{c}\mathbf{C}_{\mathbf{5}} \\
(+)\end{array}$ & $\begin{array}{c}\mathbf{C}_{\mathbf{6}} \\
(+)\end{array}$ & $\begin{array}{c}\mathbf{C}_{\mathbf{7}} \\
(-)\end{array}$ & $\begin{array}{c}\mathbf{C}_{\mathbf{8}} \\
(-)\end{array}$ & $\begin{array}{c}\mathbf{C}_{\mathbf{9}} \\
(+)\end{array}$ \\
\hline $\mathrm{L}_{1}$ & Lokasi 1 & 2,1 & 900 & Cukup Baik & 8 & 50 & Sangat Aman & 2 & 5 & 200 \\
$\mathrm{~L}_{2}$ & Lokasi 2 & 3,2 & 1200 & Baik & 7 & 100 & Aman & 3 & 4 & 300 \\
$\mathrm{~L}_{3}$ & Lokasi 3 & 2,9 & 900 & Sangat Baik & 5 & 70 & Cukup Aman & 4 & 3 & 350 \\
$\mathrm{~L}_{4}$ & Lokasi 4 & 2,5 & 2200 & Baik & 6 & 80 & Aman & 3 & 4 & 340 \\
\hline
\end{tabular}

Tabel 6. Nilai Data Kuantitatif untuk Masing-masing Kriteria

\begin{tabular}{ccccccccccc}
\hline $\begin{array}{c}\text { Kode } \\
\text { Lokasi }\end{array}$ & Lokasi & $\begin{array}{c}\mathbf{C}_{\mathbf{1}} \\
(-)\end{array}$ & $\begin{array}{c}\mathbf{C}_{\mathbf{2}} \\
(+)\end{array}$ & $\begin{array}{c}\mathbf{C}_{\mathbf{3}} \\
(+)\end{array}$ & $\begin{array}{c}\mathbf{C}_{\mathbf{4}} \\
(+)\end{array}$ & $\begin{array}{c}\mathbf{C}_{\mathbf{5}} \\
(+)\end{array}$ & $\begin{array}{c}\mathbf{C}_{\mathbf{6}} \\
(+)\end{array}$ & $\begin{array}{c}\mathbf{C}_{7} \\
(-)\end{array}$ & $\begin{array}{c}\mathbf{C}_{\mathbf{8}} \\
(-)\end{array}$ & $\begin{array}{c}\mathbf{C}_{\mathbf{9}} \\
(+)\end{array}$ \\
\hline $\mathrm{L}_{1}$ & Lokasi 1 & 2,1 & 900 & 3 & 8 & 50 & 5 & 2 & 5 & 200 \\
$\mathrm{~L}_{2}$ & Lokasi 2 & 3,2 & 1200 & 4 & 7 & 100 & 4 & 3 & 4 & 300 \\
$\mathrm{~L}_{3}$ & Lokasi 3 & 2,9 & 900 & 5 & 5 & 70 & 3 & 4 & 3 & 350 \\
$\mathrm{~L}_{4}$ & Lokasi 4 & 2,5 & 2200 & 4 & 6 & 80 & 4 & 3 & 4 & 340 \\
\hline
\end{tabular}

Perhitungan CPI untuk kriteria kedekatan dengan suplier $\left(\mathrm{C}_{7}\right)$,

$\mathrm{L}_{1} \cdot \mathrm{C}_{7}(-)=\frac{2}{2} * 100=100$

$\mathrm{L}_{2} \cdot \mathrm{C}_{7}(-)=\frac{2}{3} * 100=67$

$\mathrm{L}_{3} \cdot \mathrm{C}_{7}(-)=\frac{2}{4} * 100=50$

$\mathrm{L}_{4} \cdot \mathrm{C}_{7}(-)=\frac{2}{3} * 100=67$

Perhitungan CPI untuk kriteria usaha serupa $\left(\mathrm{C}_{8}\right)$,

$\mathrm{L}_{1} \cdot \mathrm{C}_{8}(-)=\frac{3}{5} * 100=60$

$\mathrm{L}_{2} \cdot \mathrm{C}_{8}(-)=\frac{3}{4} * 100=75$

$\mathrm{L}_{3} \cdot \mathrm{C}_{8}(-)=\frac{3}{3} * 100=100$

$\mathrm{L}_{4} \cdot \mathrm{C}_{8}(-)=\frac{3}{4} * 100=75$

Perhitungan CPI untuk kriteria kepadatan penduduk $\left(\mathrm{C}_{9}\right)$,

$\mathrm{L}_{1} \cdot \mathrm{C}_{9}(+)=\frac{200}{200} * 100=100$

$\mathrm{L}_{2} \cdot \mathrm{C}_{9}(+)=\frac{300}{200} * 100=150$

$\mathrm{L}_{3} . \mathrm{C}_{9}(+)=\frac{350}{200} * 100=175$
$\mathrm{L}_{4} \cdot \mathrm{C}_{9}(+)=\frac{340}{200} * 100=170$

Hasil perhitungan CPI di representasikan dalam matriks $\mathrm{V}_{\mathrm{ij}}$ sebagai berikut :

$V_{i j}=\left[\begin{array}{ccccccccc}100 & 100 & 100 & 160 & 100 & 167 & 100 & 60 & 100 \\ 66 & 133 & 133 & 140 & 200 & 133 & 67 & 75 & 150 \\ 72 & 100 & 167 & 100 & 140 & 100 & 50 & 100 & 175 \\ 84 & 244 & 133 & 120 & 160 & 133 & 67 & 75 & 170\end{array}\right]$

Nilai total akhir untuk masing-masing alternatif dihitung menggunakan persamaan 4 . Nilai total akhir untuk lokasi 1 ,

$$
\begin{aligned}
& \mathrm{NA}_{\text {Lokasi1 }}=(100 * 0,09)+\cdots+(100 * 0,12) \\
& \mathrm{NA}_{\text {Lokasi } 1}=9+8+13+\cdots+12=105
\end{aligned}
$$

Nilai total akhir untuk lokasi 2,

$$
\begin{gathered}
N A_{\text {Lokasi } 1}=(66 * 0,09)+\cdots+(150 * 0,12) \\
N A_{\text {Lokasi } 1}=6+11+17+\cdots+18=115
\end{gathered}
$$

Nilai total akhir untuk lokasi 3 ,

$$
\begin{gathered}
N A_{\text {Lokasi } 1}=(72 * 0,09)++\cdots+(175 * 0,12) \\
N A_{\text {Lokasi } 1}=7+8+22+\cdots+21=109
\end{gathered}
$$

Nilai total akhir untuk lokasi 4 ,

$$
\begin{gathered}
N A_{\text {Lokasi } 1}=(84 * 0,09)+\cdots+(170 * 0,12) \\
N A_{\text {Lokasi } 1}=8+20+17+\cdots+20=123
\end{gathered}
$$


Tabel 7. Hasil Perangkingan

\begin{tabular}{lll}
\hline Lokasi & Nilai Akhir & Peringkat \\
\hline Lokasi 1 & 105 & 4 \\
Lokasi 2 & 115 & 2 \\
Lokasi 3 & 109 & 3 \\
Lokasi 4 & 123 & 1 \\
\hline
\end{tabular}

Berdasarkan hasil simulasi perhitungan dengan mengimplementasikan CPI diperoleh bahwa lokasi terbaik adalah lokasi 4.

\subsection{Hasil Ujicoba Kestabilan CPI}

Ujicoba stabilitas CPI menggunakan analisis sensitivitas bobot dimensi tunggal. Pada tabel 2, disajikan bahwa bobot kriteria tertinggi $\left(\mathrm{C}_{7}\right)$ adalah 0,19 dan bobot kriteria terendah $\left(\mathrm{C}_{4}\right)$ adalah 0,05. Berdasarkan persamaan 5, diperoleh kisaran tertinggi bobot kriteria terpenting, $\mathrm{W}_{\mathrm{j}}$,

$$
W^{\prime}{ }_{j}=[0,19+(9-1) * 0,05]=0,59
$$

Kisaran bobot kriteria $\mathrm{C}_{7}$ adalah $0,01 \leq \mathrm{W}_{\mathrm{j}} \leq$ 0,59. Uji coba dilakukan dengan melakukan variasi bobot kriteria dimana bobot kriteria $\mathrm{C}_{7}$ berada dalam kisaran yang telah ditentukan, dan bobot kriteria untuk kriteria lainnya menurun dan meningkat secara proporsional .

Tabel 8. Variasi Bobot Kriteria

\begin{tabular}{cccccccccc}
\hline $\begin{array}{c}\text { Variasi Bobot } \\
\text { Kriteria }\end{array}$ & $\begin{array}{c}\text { C1 } \\
(-)\end{array}$ & $\begin{array}{c}\text { C2 } \\
(+)\end{array}$ & $\begin{array}{c}\text { C3 } \\
(+)\end{array}$ & $\begin{array}{c}\text { C4 } \\
(+)\end{array}$ & $\begin{array}{c}\text { C5 } \\
(+)\end{array}$ & $\begin{array}{c}\text { C6 } \\
(+)\end{array}$ & $\begin{array}{c}\text { C7 } \\
(-)\end{array}$ & $\begin{array}{c}\text { C8 } \\
(-)\end{array}$ & $\begin{array}{c}\text { C9 } \\
(+)\end{array}$ \\
\hline Variasi 1 & 0,11 & 0,10 & 0,15 & 0,07 & 0,11 & 0,13 & 0,01 & 0,16 & 0,14 \\
Variasi 2 & 0,1 & 0,09 & 0,14 & 0,06 & 0,10 & 0,12 & 0,11 & 0,15 & 0,13 \\
Variasi 3 & 0,087 & 0,077 & 0,127 & 0,047 & 0,087 & 0,107 & 0,21 & 0,137 & 0,117 \\
Variasi 4 & 0,075 & 0,065 & 0,115 & 0,035 & 0,075 & 0,095 & 0,31 & 0,125 & 0,105 \\
Variasi 5 & 0,062 & 0,052 & 0,102 & 0,022 & 0,062 & 0,082 & 0,41 & 0,112 & 0,092 \\
Variasi 6 & 0,051 & 0,041 & 0,091 & 0,011 & 0,051 & 0,071 & 0,5 & 0,101 & 0,081 \\
\hline
\end{tabular}

Tabel 8. Hasil Uji Coba Analisis Sensitivitas Bobot

\begin{tabular}{clccccccccccc}
\hline Variasi & Lokasi & $\mathrm{C}_{1}$ & $\begin{array}{c}\mathrm{C}_{2} \\
(-)\end{array}$ & $\begin{array}{c}\mathrm{C}_{3} \\
(+)\end{array}$ & $\begin{array}{c}\mathrm{C}_{4} \\
(+)\end{array}$ & $\begin{array}{c}\mathrm{C}_{5} \\
(+)\end{array}$ & $\begin{array}{c}\mathrm{C}_{6} \\
(+)\end{array}$ & $\begin{array}{c}\mathrm{C}_{7} \\
(-)\end{array}$ & $\begin{array}{c}\mathrm{C}_{8} \\
(-)\end{array}$ & $\begin{array}{c}\mathrm{C}_{9} \\
(+)\end{array}$ & Nilai Akhir & Peringkat \\
\hline \multirow{3}{*}{ Bariasi } & Lokasi 1 & 11 & 11 & 15 & 12 & 11 & 22 & 1 & 10 & 14 & 107 & 4 \\
Bobot 1 & Lokasi 2 & 7 & 14 & 20 & 10 & 23 & 18 & 1 & 12 & 21 & 126 & 2 \\
& Lokasi 3 & 8 & 10 & 26 & 7 & 16 & 13 & 1 & 16 & 25 & 122 & 3 \\
& Lokasi 4 & 9 & 25 & 20 & 9 & 18 & 18 & 1 & 12 & 24 & 137 & 1 \\
Variasi & Lokasi 1 & 10 & 9 & 14 & 10 & 10 & 20 & 11 & 9 & 13 & 106 & 4 \\
Bobot 2 & Lokasi 2 & 7 & 12 & 19 & 8 & 20 & 16 & 7 & 11 & 20 & 120 & 2 \\
& Lokasi 3 & 7 & 9 & 23 & 6 & 14 & 12 & 6 & 15 & 23 & 115 & 3 \\
& Lokasi 4 & 8 & 22 & 19 & 7 & 16 & 16 & 7 & 11 & 22 & 129 & 1 \\
Variasi & Lokasi 1 & 9 & 8 & 13 & 8 & 9 & 18 & 21 & 8 & 12 & 104 & 4 \\
Bobot 3 & Lokasi 2 & 6 & 10 & 17 & 7 & 17 & 14 & 14 & 10 & 18 & 113 & 2 \\
& Lokasi 3 & 6 & 8 & 21 & 5 & 12 & 11 & 11 & 14 & 20 & 107 & 3 \\
& Lokasi 4 & 7 & 19 & 17 & 6 & 14 & 14 & 14 & 10 & 20 & 121 & 1 \\
Variasi & Lokasi 1 & 8 & 7 & 12 & 6 & 8 & 16 & 31 & 8 & 11 & 103 & 3 \\
Bobot 4 & Lokasi 2 & 5 & 9 & 15 & 5 & 15 & 13 & 21 & 9 & 16 & 107 & 2 \\
& Lokasi 3 & 5 & 7 & 19 & 4 & 11 & 10 & 16 & 13 & 18 & 101 & 4 \\
& Lokasi 4 & 6 & 16 & 15 & 4 & 12 & 13 & 21 & 9 & 18 & 114 & 1 \\
Variasi & Lokasi 1 & 6 & 5 & 10 & 4 & 6 & 14 & 41 & 7 & 9 & 102 & 2 \\
Bobot 5 & Lokasi 2 & 4 & 7 & 14 & 3 & 12 & 11 & 27 & 8 & 14 & 101 & 3 \\
& Lokasi 3 & 4 & 5 & 17 & 2 & 9 & 8 & 21 & 11 & 16 & 94 & 4 \\
& Lokasi 4 & 5 & 13 & 14 & 3 & 10 & 11 & 27 & 8 & 16 & 106 & 1 \\
Variasi & Lokasi 1 & 5 & 4 & 9 & 2 & 5 & 12 & 50 & 6 & 8 & 101 & 1 \\
Bobot 6 & Lokasi 2 & 3 & 5 & 12 & 2 & 10 & 9 & 33 & 8 & 12 & 95 & 3 \\
& Lokasi 3 & 4 & 4 & 15 & 1 & 7 & 7 & 25 & 10 & 14 & 88 & 4 \\
& Lokasi 4 & 4 & 10 & 12 & 1 & 8 & 9 & 33 & 8 & 14 & 100 & 2 \\
\hline
\end{tabular}


Pada uji coba variasi 1, 2 dan 3 diperoleh urutan perangkingan rekomendasi lokasi usaha adalah Lokasi 4 - Lokasi 2 - Lokasi 3 - Lokasi 1. Pada ujicoba variasi 4 diperoleh urutan perangkingan rekomendasi lokasi usaha adalah Lokasi 4 Lokasi 2 - Lokasi 1 - Lokasi 3. Pada ujicoba variasi 5 diperoleh urutan perangkingan rekomendasi lokasi usaha adalah Lokasi 4 Lokasi 1 - Lokasi 2 - Lokasi 3. Pada ujicoba variasi 5 diperoleh urutan perangkingan rekomendasi lokasi usaha adalah Lokasi 1 Lokasi 4 - Lokasi 2 - Lokasi 3.

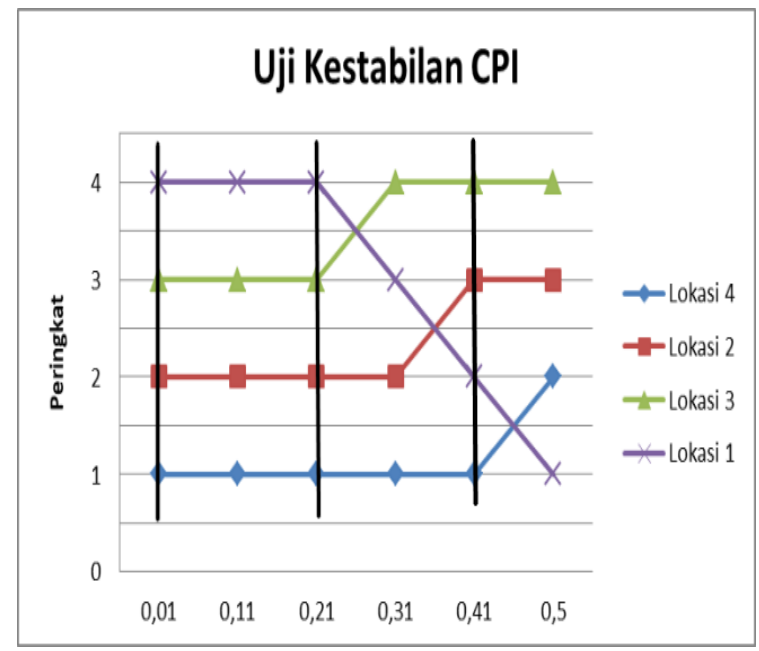

\section{Gambar 1. Hasil Uji Sensivitas Bobot CPI}

Berdasarkan gambar 1 diatas, diperoleh interval stabilitas bobot lokal CPI adalah $0,01 \leq \mathrm{CPI} \leq 0,41$ dan interval stabilitas bobot global adalah $0,01 \leq \mathrm{CPI} \leq 0,21$. Alternatif Lokasi 4 berada di posisi peringkat pertama didalam kisaran nilai interval stabilitas bobot lokal dan semua alternatif berada pada posisi peringkat yang tidak berubah dalam kisaran nilai interval stabilitas bobot global.

\section{SIMPULAN}

Dari uraian diatas dapat di tarik kesimpulan :

1. Composite Performance Index (CPI) sebagai salah satu metode dalam Multi Criteria Decision Making (MCDM) dapat memilih lokasi UMKM dengan baik, dimana perubahan bobot kriteria tidak berpengaruh signifikan terhadap perubahan peringkat alternatif terbaik.

2. Interval stabilitas bobot lokal terjadi pada kisaran kriteria terpenting $\left(\mathrm{C}_{7}\right)$ adalah $0,01 \leq \mathrm{CPI} \leq 0,4$, dimana peringkat alternatif terbaik (Lokasi 4) tidak berubah.

3. Interval stabilitas bobot global terjadi pada kisaran kriteria terendah $\left(\mathrm{C}_{4}\right)$ adalah $0,01 \leq \mathrm{CPI} \leq 0,21$, dimana peringkat semua alternatif tidak berubah.

\section{DAFTAR PUSTAKA}

Arlida, C.P., Suryatiningsih, Adi, T. N. (2012) 'Sistem Pendukung Keputusan untuk Menentukan Jenis Bibit Tanaman pada Penjualan Online', in Konferensi Nasional ICT-M Politeknik Telkom (KNIP). Bandung, pp. 38-42.

Diana (2016) 'Kelayakan Bisnis Menerapkan Simple Multi Attribute Rating Technique ( Smart )', Ilmiah Matrik, 18, pp. 113-124.

Diana (2017) 'Usaha Waralaba Menggunakan Metode Bayes', Jurnal Ilmiah MATRIK, 19(1), pp. 41-52.

Diana (2018) Metode dan aplikasi sistem pendukung keputusan. 1st edn. Yogyakarta: Penerbit Deepublish.

Fu'ad, E. N. (2015) 'Pengaruh Pemilihan Lokasi Terhadap Kesuksesan Usaha Berskala Implementasi Composite Performance Index pada Multi Criteria Decision... ... (Diana) 177 
Mikro/Kecil Di Komplek Shopping Centre Jepara', Fakultas Ekonomi dan Bisnis, Universitas Islam Nahdlatul Ulama Jepara, Vol. 30 No(1), pp. 56-67. doi: 10.1016/j.foodqual.2012.04.002.

Hanggita, A. T. (2018) 'Analisis Faktor Pemilihan Lokasi Usaha Jasa pada UMKM di Kecamatan Paciran', Jurnal Manajemen Bisnis, 8(02), pp. 167-176.

Karande, P., Zavadskas, E. K. and Chakraborty, S. (2016) 'A study on the ranking performance of some MCDM methods for industrial robot selection problems', International Journal of Industrial Engineering Computations, 7(3), pp. 399422. doi: $10.5267 /$ j.ijiec.2016.1.001.

Karismariyanti, M. (2011) 'Simulasi Pendukung Keputusan Penerima Beasiswa Menggunakan Metode Composite Performance Index', Jurnal Teknologi Informasi, 1(2), pp. 54-59.
Pandian, G. S., Jawahar, N. and Nachiappan, S. P. (2013) 'Composite Performance Index for Sustainability', Journal of Environmental Science, Toxicology And Food Technology, 3(1), pp. 91-102. doi: 10.9790/240203191102 .

Rahim, R. et al. (2017) 'Composite performance index for student admission', International Journal of Research In Science \& Engineering, 3(3), pp. 68-74. Available at: http://ijrise.org/asset/archive/17May9.pdf.

Rekik, R. et al. (2016) 'Using multiple criteria decision making approaches to assess the quality of web sites', International Journal of Computer Science and Information Security, 14(7), pp. 747-761.

Rostamzadeh, R., Ismail, K. and Bodaghi Khajeh Noubar, H. (2014) 'An application of a hybrid MCDM method for the evaluation of entrepreneurial intensity among the SMEs: A case study', Scientific World Journal, 2014. doi: 10.1155/2014/703650. 